\title{
SLIGHT SOIL DEACIDIFICATION COMPROMISE THE GROWTH AND THE ALUMINUM ACCUMULATION IN Qualea cordata PLANTS
}

\author{
ALVIM, M. N. ${ }^{1}-$ FRANÇA, M. G. C. ${ }^{*}-$ RAMOS, F. T. ${ }^{2}-$ ZONTA, E. $^{3}-$ NASCENTES, C. C. ${ }^{1}$ \\ ${ }^{1}$ Departamento de Botânica, Universidade Federal de Minas Gerais, Av. Antônio Carlos, 6627, \\ Pampulha, Belo Horizonte, MG, 31270-901, Brasil \\ ${ }^{2}$ Ramboll, Rua Paraiba, 550, Funcionários, Belo Horizonte, MG, 30130-140, Brasil \\ ${ }^{3}$ Departamento de Solos, Universidade Federal Rural do Rio de Janeiro, BR-465, $\mathrm{km} 7$, \\ Seropédica, Rio de Janeiro, RJ, 23897-000, Brasil \\ *Corresponding author \\ e-mail:marcel@icb.ufmg.br; phonelfax: + 55-31-34092671 \\ (Received 12 $2^{\text {th }}$ Jul 2017; accepted $5^{\text {th }}$ Oct 2017)
}

\begin{abstract}
Soil acidity and aluminum presence may reduce plant growth worldwide. In several cases, these two parameters, either alone or associated, can lead to plant constraints, which is barely known in natural ecosystems. In order to address these constraints, current model of study is Qualea cordata, an endemic species of Brazilian impoverished soil of rupestrian fields. Plants were grown, both in very acidic soil and in little deacidificated soil. After 6 months of growth in two acidic soil conditions and aluminum presence, the accumulation and dry biomass partitioning and content of nitrogen, calcium, magnesium, phosphorus, aluminum and chloroplastic pigments were evaluated and also chlorophyll fluorescence was obtained in intact plants. The soil deacidification induced an increase of mineral element contents in the leaves, however, lower total plant biomass and aluminum accumulation, also induced differential biomass partitioning and greater carotenoid levels. Regardless of the soil acidity, the levels of chlorophyll were not altered even in photosynthetic parameters. The results highlighted the resilience of this species to natural and very acidic soil conditions, indicating the need and the beneficial effect of aluminum accumulation in this specie.
\end{abstract}

Keywords: aluminum resilience, metal accumulator, soil pH, Vochysiaceae

\section{Introduction}

Acidic soil with aluminum (Al) availability is one of the environmental factors which compromises plant growth in many parts of the world, because in such soil the increase of this metal availability reduces plant development in most cases (Poschenrieder et al., 2008; Kochian et al., 2015). In general, the Brazilian savanna soil, including the rupestrian fields, is acidic, oligotrophic and containing high $\mathrm{Al}$ concentrations (Oliveira et al., 2015). However, throughout the world, some plants not only tolerate Al, but also accumulate significant quantities in the shoots and are therefore identified as Al accumulators (Jansen et al., 2002a), for example, Camellia sinensis (Theaceae) leaves are used for tea and may accumulate up to $30,000 \mathrm{mg} \mathrm{Al} \mathrm{kg}^{-1}$ of dry mass (Matsumoto et al., 1976). Many of these $\mathrm{Al}$ accumulating plants are found in the Brazilian flora, especially species of the Melastomataceae, Vochysiaceae and Rubiaceae families (Souza et al., 2015), and very little is known about the ecological adaptation traits of these species.

Arboreal species or bushes frequently found in rupestrian fields such as those represented by the Vochysiaceae family, including Qualea grandiflora, Q. parviflora, 
Vochysia thyrsoidea, V. haenkeana, as well as Melastomataceae (Miconia spp) and Rubiaceae (Palicourea rigida) families, are known to be Al accumulators (Jansen et al., 2002b; Olivares et al., 2010). Some of these species have notable behaviors in terms of adaptation to soluble $\mathrm{Al}$ in the soil. For example, contrary to expectations, high $\mathrm{Al}$ concentrations in leaves are not associated with low essential nutrient content. While some $\mathrm{Al}$ accumulating plants are restricted to oligotrophic soil, others are indifferent to soil fertility (Haridasan, 2000).

The elevated $\mathrm{Al}$ content found in shoots of the $\mathrm{Al}$ accumulators suggests that these plants have an Al uptake and translocation system which cannot be found in nonaccumulating plants (Ma and Hiradate, 2000). Considering the arboreal native species from rupestrian fields, a small number of studies have been conducted. Most of them evaluate the quantitative plant $\mathrm{Al}$ accumulation obtained in situ and are rarely related to ecological adaptations and to controlled alterations of abiotic factors. Some authors argue that the capacity of $\mathrm{Al}$ accumulation is a determining evolving trait in these species to the point that some of them cannot survive without this metal present in the soil (Jansen et al., 2002a). Floristic studies have shown that the Vochysiaceae family has many endemic species in this ecosystem (Shimizu and Yamamoto, 2012) and that in its majority; it has an accumulating trait of more than $1000 \mathrm{mg} \mathrm{Al} \mathrm{Kg}^{-1}$ in the shoots (Jansen et al., 2002a). These species are spread out in the Espinhaço Mountains in Brazil, and in other areas of the South American region (Shimizu and Yamamoto, 2012). In terms of growth, in general, plants respond positively to soil deacidification, including some native plants of different ecosystems (Haridasan, 2000). Thus, the hypothesis in this study was that minor alterations in soil acidity may interfere in the mineral nutrient and $\mathrm{Al}$ accumulation as well as plant development of Qualea cordata (Vochysiaceae). The relationship between changes of the acidic soil conditions and its related nutrients and $\mathrm{Al}$ levels were verified for the growth of this plant of the Brazilian Cerrado and rupestrian field.

\section{Materials and Methods}

\section{Plant material and acidic soil conditions}

Qualea cordata plants are an arboreal species, seed propagated, that grow in mesotrophic soil rich in $\mathrm{Al}$ and also occur in dystrophic and very acid soils (Haridasan, 2008; França, 2015). The species is found in South America, from Brazil to Bolivia, in savannahs, the Atlantic and cost rainforest (Correa, 1926). The plants grew in a greenhouse from the botanic department of the Federal University of Minas Gerais, Brazil. Seeds and soil used in the experiments were collected in rupestrian fields of the Serra do Cipó National Park, Santana do Riacho, Minas Gerais. The harvested fruits were left in the open at room temperature for 30 days for drying and opened to allow seed removal. After this period, they were kept in the freezer until use.

The soil was collected at $25 \mathrm{~cm}$ of depth, in the site of occurrence of this species using a shovel, and the vegetation and organic remains were removed. The soil fertility was analyzed according to Claessen et al. (1997) using the EMBRAPA method in the soil fertility laboratory at the Federal Rural University of Rio de Janeiro.

Seeds were sterilized in 5\% hypochlorite for $5 \mathrm{~min}$ and then washed 3 times in deionized water. Germination was conducted in plastic gerbox plates covered with 2 germination papers moistened with deionized water, conditioned in germination chamber for 7 days at $30^{\circ} \mathrm{C}$ and for a $12 \mathrm{~h}$ photoperiod. After germination, well- 
developed seedlings of the same size were selected for experiments. For growth assays, the seedlings were transplanted to $2 \mathrm{~L}$ pots containing the respective soil with or without liming treatment and no fertilizers. The slight variation in soil deacidification was performed by liming $\left(\mathrm{CaCO}_{3}\right)$, aiming at increasing the soil acidity in one unit only from 4 to 5 , which reduces the $\mathrm{Al}$ availability by $50 \%$.

\section{Growth evaluation and leaf mineral element content}

Plants $(n=10)$ were grown in two different soil acid conditions in the greenhouse for 6 months and irrigated on alternate days with distilled water up to water saturation of the soil. After this period, plants were carefully withdrawn from the pots and the shoot and root lengths were measured. After this, the plants from both soil treatments were separated into stalk, roots and leaves, and then taken to a forced air oven at $60^{\circ} \mathrm{C}$ until constant mass, to obtain the corresponding dry mass of parts and total biomass. The relation of roots to shoots $(\mathrm{R}: \mathrm{S})$ was calculated starting from these values.

The leaf content of the elements iron $(\mathrm{Fe})$, aluminum $(\mathrm{Al})$, magnesium $(\mathrm{Mg})$, calcium $(\mathrm{Ca})$, nitrogen $(\mathrm{N})$ and phosphorus $(\mathrm{P})$ was obtained after dry mass digestion in sulfuric acid and hydrogen peroxide. The $\mathrm{P}$ content was determined colorimetrically at $410 \mathrm{~nm}$ using ammonium vanadomolybdate and $\mathrm{N}$ content, according to the Kjeldahl procedure (Allen, 1989). The $\mathrm{Al}, \mathrm{Ca}$ and $\mathrm{Mg}$ content was obtained through flame atomic absorption spectrometry (FAAS) using Varian, model AA240FS (Mulgrave, Australia).

\section{Chloroplastic pigments and photosynthetic evaluation}

For photosynthetic pigment contents, three leaf discs with $1 \mathrm{~cm}$ diameter were withdrawn from a totally expanded leaf of five individuals of two soil treatments and submerged in $5 \mathrm{~mL}$ of $80 \%$ acetone for $48 \mathrm{~h}$ at $4^{\circ} \mathrm{C}$. These tissues were macerated, centrifuged and the supernatant was used for spectrophotometric determination of chlorophyll $a$, chlorophyll $b$ and carotenoids in the following wave-lengths 470, 646 and $663 \mathrm{~nm}$, respectively. The chloroplastic pigment levels were determined as proposed by Lichtethaler and Wellburn (1983).

The photosynthetic parameters were evaluated on a typical day through chlorophyll fluorescence, measured with a modulated fluorescence meter (MINI-PAN, WalzGermany), and the potential quantic yield values (Fv/Fm) and the effective quantum yield $(\Delta \mathrm{F} / \mathrm{Fm}$ ') was obtained in plants from the acid and less acidic soil. The $\mathrm{Fv} / \mathrm{Fm}$ from the photosystem II was evaluated in the early morning and the leaves were adapted in the dark for $30 \mathrm{~min}$, being that $\mathrm{Fv} / \mathrm{Fm}=\left(\mathrm{Fm}-\mathrm{F}_{0}\right) / \mathrm{Fm}$ in which Fm refers to the maximum fluorescence and $\mathrm{F}_{0}$ to the basal fluorescence. Concerning the $\Delta \mathrm{F} / \mathrm{Fm}$ ' values, these were determined being that $\Delta \mathrm{F} / \mathrm{Fm}^{\prime}=\left(\mathrm{Fm}^{\prime}-\mathrm{F}\right) / \mathrm{Fm}$ ', in which $\mathrm{F}$ is the chlorophyll fluorescence of the sample adapted to the light and Fm' to the maximum fluorescence of samples with saturating pulse.

\section{Statistical analysis}

Variance analysis (ANOVA) was carried out to analyze obtained data in the assays. The software used was JMP 5 SAS (Statistical Analysis System 1980, U.S.) and the Tukey test at $5 \%$ of probability was employed to compare the obtained means. 


\section{Results}

\section{Acidic soil and nutrient levels and plant growth evaluation}

The results of fertility soil analysis from the site of occurrence of $Q$. cordata revealed soil $\mathrm{pH}$ values extremely acid with high aluminum content. Also, the nutrient content is low, characterizing the soil as impoverished and dystrophic (Table 1).

Table 1. Fertility analysis of soil collected from the site of occurrence of Qualea cordata Spreng. $\mathrm{H} 2 \mathrm{O}=\mathrm{pH}$ in water, $\mathrm{Ca}, \mathrm{Mg}$ and $\mathrm{P}=$ calcium, magnesium and phosphorus exchangeable, $O M=$ organic matter, $V=$ base saturation, $m=$ aluminum saturation. Data from 3 composite samples.

\begin{tabular}{|c|c|c|c|c|c|}
\hline pH & cmol & $\mathrm{dm}^{-3}$ & $\mathrm{mg} \mathrm{dm}^{-3}$ & dag $\mathrm{kg}^{-1}$ & $\%$ \\
\hline $\mathrm{H}_{2} \mathrm{O}$ & $\mathrm{Ca}$ & $\mathrm{Mg}$ & $\mathrm{P}$ & $\mathrm{OM}$ & $\mathrm{V} \quad \mathrm{m}$ \\
\hline 4.0 & 0.29 & 0.06 & 4.91 & 1.89 & 6.286 \\
\hline
\end{tabular}

The less acidic soil affected negatively and significantly the $Q$. cordata plant growth. The plants grown in more acidic soil presented greater increase in root, leaf and shoot dry weight as well as the total dry weight in comparison to those grown in less acid soil. However, there was no variation in dry weight of the stem or in the root and shoot ratio (R:S) (Figure 1). After 180 days of growth, the increment of dry biomass of root, shoot and total biomass of plants from more acidic soil was significantly higher compared to the same values of plants from less acidic soil. However, the R:S ratio was not significant.

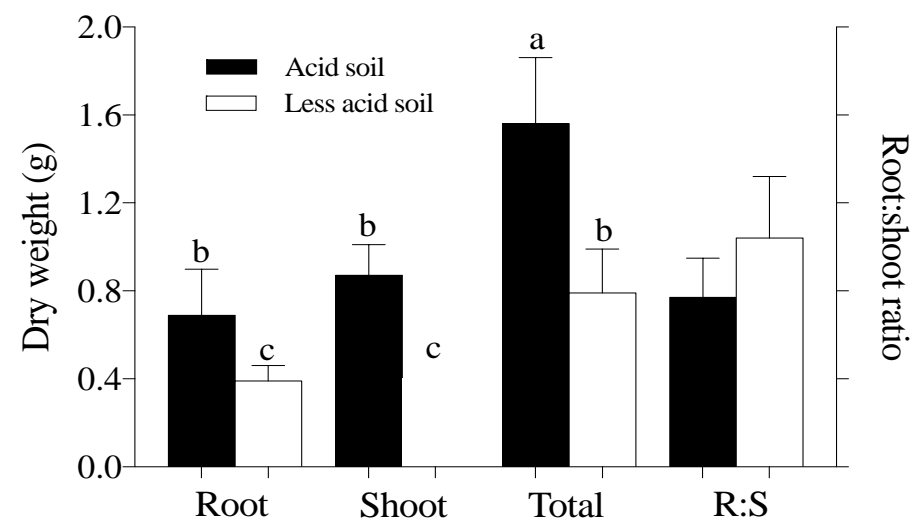

Figure 1. Root, shoot and total dry weight ( $\mathrm{g}$ ) and root: shoot ratio of Qualea cordata plants after 6 months of growing in more acidic soil and also in less acidic soil. Means followed by the same lowercase letter in the column did not differ significantly by Tukey test at $P \leq 0.05$. Means followed by standard deviation with $n=10$.

Regarding the total plant height (Table 2), those grown in more acidic soil presented an average apex root length of $43.9 \mathrm{~cm}$, while those obtained in the less acidic soil presented $45.0 \mathrm{~cm}$. However, the greatest length of roots was found in plants in the less acid soil, and there was a difference in the shoot height of plants in this soil in contrast to those obtained after growth from less acidic soil. 
Table 2. Root, shoot and total length (cm) of the Qualea cordata plants after 6 months of growing in more acidic soil and also in less acidic soil. Means followed by the same lowercase letter in the column did not differ significantly by Tukey test at $P \leq 0.05$. Means followed by standard deviation with $n=10$.

\begin{tabular}{cccc}
\hline & Root & Shoot & Total \\
\hline Acid soil & $27.27 \pm 1.72 \mathrm{~b}$ & $16.61 \pm 2.95 \mathrm{~b}$ & $43.89 \pm 2.09 \mathrm{~b}$ \\
Less acid soil & $32.20 \pm 2.89 \mathrm{a}$ & $12.79 \pm 1.94 \mathrm{c}$ & $44.99 \pm 3.48 \mathrm{~b}$ \\
\hline
\end{tabular}

\section{Leaf mineral element analysis}

In terms of the mineral element content in leaves, the greatest values of $\mathrm{N}, \mathrm{P}, \mathrm{Ca}$ and $\mathrm{Mg}$ were found on leaves of plants grown in less acidic soil (Figure 2). Contrastingly, the $\mathrm{Al}$ leaf content was greater in plants grown in more acidic soil.

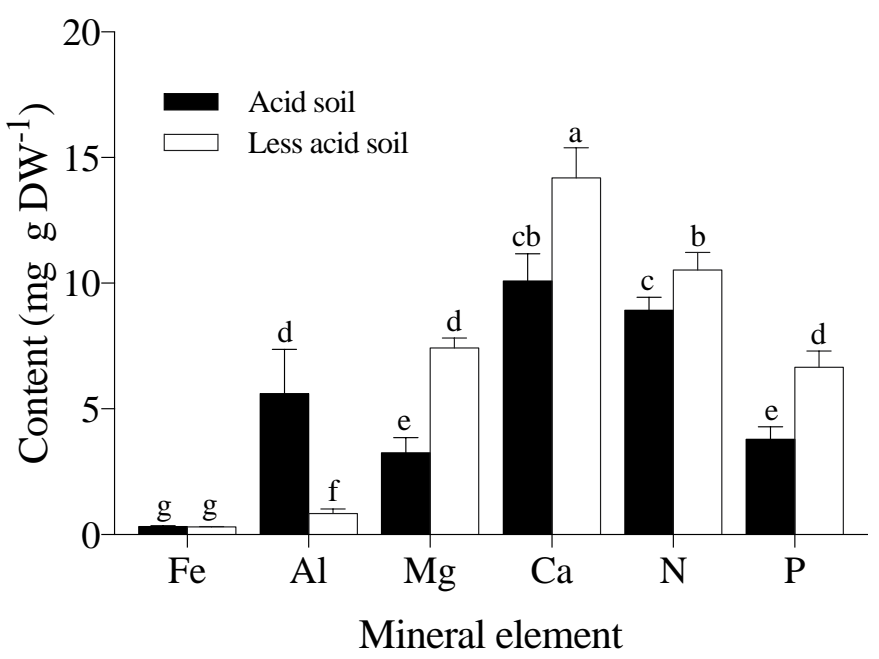

Figure 2. Content of elements iron ( $\mathrm{Fe}$ ), aluminum ( $\mathrm{Al}$ ), magnesium ( $\mathrm{Mg}$ ), calcium (Ca), nitrogen $(N)$ and phosphorus $(P)$ in the leaves of Qualea cordata after 6 months of growing in more acidic soil and also in less acidic soil. Means and standard deviation with $n=3$.

\section{Chloroplastic pigments and photosynthetic evaluation}

The total chlorophyll content, distributed among $a$ and $b$, was not altered in plants from less acidic soil (Table 3), but the carotenoid content and the chlorophyll: carotenoid ratio changed, where the carotenoid content was two times greater in those plants grown in this deacidification soil.

The analysis of fluorescence of chlorophyll a (Figure 3) indicated discrete lower values of effective quantum yield $\left(\Delta \mathrm{F} / \mathrm{F}^{\prime} \mathrm{m}\right)$ and potential $(\mathrm{Fv} / \mathrm{Fm})$ quantum yield in the early morning hours in plants from more acidic soil. The Fv/Fm values remained below 0.8 and reduced progressively in the evaluated time between 7 am and $1 \mathrm{pm}$. However, the $\Delta \mathrm{F} / \mathrm{F} ' \mathrm{~m}$ values diminished drastically at $9 \mathrm{am}$, raising at $10 \mathrm{am}$ and decreasing again and keeping constant from as of $12 \mathrm{pm}$. At the same time, the plants cultivated in more 
acidic soil presented values lower that 0.77 for both parameters. The $\Delta \mathrm{F} / \mathrm{F}$ 'm values decreased at 9 am and remained below 0.46 during measurements. The variations of these parameters were similar regardless of the soil treatments, but there was a less significant decrease of $\Delta \mathrm{F} / \mathrm{F}^{\prime} \mathrm{m}$ in plants grown in more acidic soil, without statistical differences between soil treatments.

Table 3. Chloroplastic pigment contents ( $\mu \mathrm{g} \mathrm{cm}-2$ ) in leaves of Qualea cordata plants after 6 months of growing in more acidic soil and also in less acidic soil. Means followed by the same lowercase letter in the column did not differ significantly by Tukey test at $P \leq 0.05$ with $n=5$. Chl $=$ Chlorophyll; $C x=$ carotenoids.

\begin{tabular}{cccccc}
\hline & Chl $\boldsymbol{a}$ & Chl $\boldsymbol{b}$ & Cx & Total $\boldsymbol{C h l}$ & $\boldsymbol{C h l / C x}$ \\
\hline Acid soil & $16 \mathrm{a}$ & $9 \mathrm{a}$ & $3 \mathrm{~b}$ & $25 \mathrm{a}$ & $8.6 \mathrm{a}$ \\
Less acid soil & $21 \mathrm{a}$ & $8 \mathrm{a}$ & $7 \mathrm{a}$ & $29 \mathrm{a}$ & $4.0 \mathrm{~b}$ \\
\hline
\end{tabular}

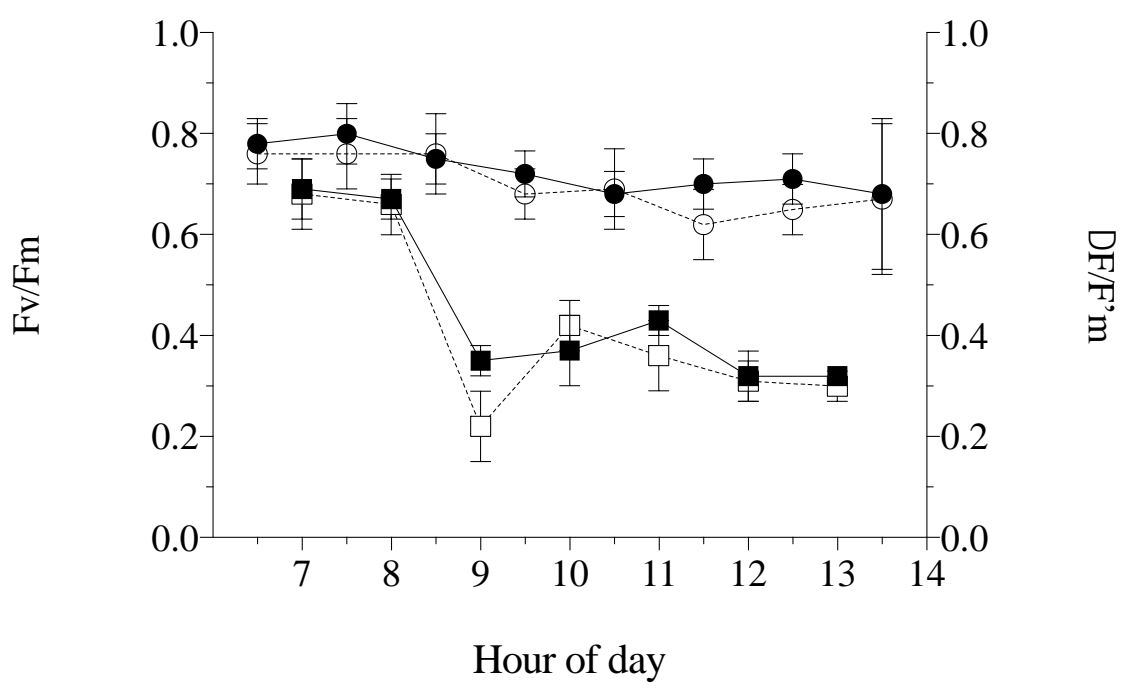

Figure 3. Potential quantum yield $(F v / F m)$ (circles) and effective quantum yield $(\Delta F / F$ ' $m)$ (squares) in the leaves of Qualea cordata after 6 months of growing in more acidic soil (white symbol) and also in less acidic soil (black symbol). Measures obtained on a clear day from 6:30 am to 1:30 pm. Means and standard deviation with $n=3$.

\section{Discussion}

\section{Soil nutrient levels and plant growth evaluation}

The soil nutrient analysis at the occurrence site of $Q$. cordata revealed very low values of the base saturation such as the content of $\mathrm{P}, \mathrm{Ca}$ and $\mathrm{Mg}$, and organic matter as it has been highlighted for rupestrian field soils (Baligar et al., 1995; Oliveira et al., 2015). Contrastingly, elevated values of $\mathrm{Al}$ saturation were found, making the ion $\mathrm{Al}$ the most predominant cation (Benites et al., 2003). However, the acidity and elevated Al saturation found on site were above those generally found in the Brazilian Cerrado (Baligar et al., 1995). Despite the elevated acidity, excessive Al content and 
impoverished soil that were found, the greatest total biomass accumulation was evident in plants that were grown in this soil, and the shoot was larger in comparison to the roots, that is, a greater investment in structural carbon took place in the shoot. Contrastingly, plants from less acidic soil, there was an equitable partition between shoot and roots. Considering the present chemical soil conditions, the results suggest that the photoassimilated drain in the roots was as strong as of that in the shoots. For Miconia albicans, Haridasan (2008) showed that when plants grow in acidic and fertile soil, there was a greater increase in height and biomass, compared to those from acidic and oligotrophic soil, and in alkaline soil, plant growth was significantly less than in those from acidic and impoverished soil. In the present study, there were no nutrients added to the soil, but deacidification was enough to modify the carbon partition. The results also showed a larger carbon displacement for biochemical purposes due to the smaller biomass incorporation of plants in less acidic soil.

There was no difference in the root: shoot $(\mathrm{R}: \mathrm{S})$ mass ratio obtained in plants that were grown in less acidic soil, but in relation to the plant length, this condition favored an increase in root size but not in the shoot. In the more acidic soil, a larger mass and a shorter root were indicators of a greater root diameter, and the inversion of these parameters in the less acidic soil suggests thinner roots. The greatest root system length in less acidic soil can be related to alterations in soil nutrient to improve the root uptake system, however, it is also considered that even an Al tolerant plant develops symptoms associated with metal toxicity, such as the thickening and shortening of roots (Silva et al., 2014).

\section{Soil and leaves mineral content}

It is known that soil deacidification promotes $\mathrm{Al}$ and $\mathrm{Fe}$ precipitation which is exchangeable, and reduces $\mathrm{P}$ precipitation, increasing labile $\mathrm{P}$ fraction (Souza et al., 2007). This was confirmed through the greatest $P$ content found in leaves. A large $N$ content was also observed in plant leaves from less acidic soil; however, the greatest presence of these elements did not induce the greatest growth of shoots or biomass accumulation. The $\mathrm{N}$ and $\mathrm{P}$ contents found in $Q$. cordata leaves, after growth in both acidic soil conditions, were similar to those found in $Q$. grandiflora and $Q$. parviflora (Nardoto et al., 2006) and other arboreal species in natural field conditions (Delitti et al., 2006). The $\mathrm{Ca}$ and $\mathrm{Mg}$ contents in leaves from less acidic soil increased significantly, mainly the Mg content with values nearly twice as high and this response had already been previously reported in other native and cultivated plant species of this ecosystem (Furtini Neto, 1999). In Plantago almogravensis, Al hyperaccumulator plant, the concentrations of $\mathrm{Ca}$ and $\mathrm{Mg}$ in the shoot were maintained along the $\mathrm{Al}$ gradient (Serrano et al., 2011). In Q. cordata the greatest content of $\mathrm{N}, \mathrm{Ca}, \mathrm{Mg}$ and $\mathrm{P}$ in leaves, despite not having induced the greatest biomass accumulation in plants, is closely related to the greatest uptake of these nutrients due to soil deacidification, and to the root system length which was approximately $20 \%$ higher.

According to Jansen et al. (2002b) the Al content found in leaves of $Q$. cordata $\left(5.6 \pm 1.77 \mathrm{mg} \mathrm{g}^{-1}\right)$ from more acidic soil allows this species to be included into the group of $\mathrm{Al}$ accumulating plants. However, in plant leaves from the less acidic soil the Al content found was significantly reduced, different than what was found by Haridasan (2000), who said that the increase of oligotrophic soil $\mathrm{pH}$ and the higher Ca content in mesotrophic soil did not reduce the $\mathrm{Al}$ accumulation in $\mathrm{Al}$ accumulating plants. The reduction of $\mathrm{Al}$ and biomass accumulation in plants from less acidic soil indicates a 
relation of this metal to the growth of $Q$. cordata. Although these observations refer to the involvement of $\mathrm{Al}$ in the cell physiology, there is still no definition of its role in the plant metabolism, even though some authors consider the actions of $\mathrm{Al}$ in plants to be beneficial (Haridasan, 2000; Pilon-Smits et al., 2009; Hajiboland et al., 2013). Recently, in Camellia sinensis, a hyper $\mathrm{Al}$ accumulating plant, the toxic fluorine effect was relieved in the presence of $\mathrm{Al}$ (Yang et al., 2016). In rice, it was also found that $\mathrm{Al}$ relieves Mn toxicity (Wang et al., 2015). Watanabe et al. (2005) evaluated the beneficial effects of $\mathrm{Al}$ in the growth of Melastoma malabathricum and when its roots were exposed to $0.5 \mathrm{mM}$ of $\mathrm{Al}$, an increase in root growth and $\mathrm{Al}$ accumulation in leaves were observed. This only took place in plants grown in complete nutrient solution, evidencing that without nutrients there was no stimulatory effect of Al. Contrastingly, it is expected that soil deacidification may reduce the availability of some micronutrients (Buni, 2014), which can constrain plant growth. In natural acidic soil conditions with higher Al content, Olivares et al. (2010) highlights the positive correlation between $\mathrm{Al}, \mathrm{Fe}$ and $\mathrm{Zn}$ leaf content in 19 Melastomataceae species, some being $\mathrm{Al}$ accumulators.

\section{Chloroplastic pigments and photosynthetic evaluation}

No changes were observed in the chloroplastic pigment of plants from less acidic soil, except the carotenoid content. Although an increase was expected, the chlorophyll content remained unchanged, since there is a positive correlation to the $\mathrm{N}$ content (Verhoeven et al., 1997). Interestingly, despite the less acidic soil plants having accumulated more $\mathrm{N}$, it was not converted to more chlorophyll synthesis that could enhance the photosynthetic capacity. It is probable that the $\mathrm{N}$ was conducted for enzyme synthesis for the metabolism of other nutrients and perhaps if the soil organic matter content were higher, the greatest $\mathrm{N}$ availability/uptake could have enhanced photosynthetic activity. Haridasan (2008), cultivated Miconia albicans and Vochysia thyrsoidea in calcareous soil and observed leaf chlorosis. This symptom disappeared in these plants removed to acidic soil whereas in $Q$. cordata, leaf chlorosis was not observed. Also, in $Q$. grandiflora, $\mathrm{Al}$ enters the chloroplasts without apparent damage to this organelle (Andrade et al., 2011). In relation to the carotenoid content, Franco et al., (2007) suggested that zeaxanthin plays an important role in the dissipation of nonphotochemical energy in trees at moments of higher irradiance. Thus, the highest carotenoid content found in plants from less acidic soil suggests that the change in soil acidity generated the need for more photoprotective capacity, evidenced by the increase in $C h l:$ Cx ratio.

Chlorophyll fluorescence data indicated chronic photoinhibition in Q. cordata leaves in the evaluated time period. The performance of the photosynthetic apparatus observed by $\mathrm{Fv} / \mathrm{Fm}$ and $\Delta \mathrm{F} / \mathrm{F}$ 'm did not change in plants from less acidic soil, indicating that lower carbon incorporation would result in greater damage to photosystem II, as often reported in plants under stress due to the lack or excess of boron (Pinho et al., 2010), nitrogen (Tripodi and Sievering, 2010) or copper (Padua et al., 2010). The slight photoinhibition observed since dawn $(\mathrm{Fv} / \mathrm{Fm}<0.8)$ became more pronounced with the increase of irradiance. Franco et al. (2007), demonstrated similar behavior in Schefflera macrocarpa and Ouratea hexasperma and suggested that increased vulnerability to photoinhibition in the morning was reversed by the cycle activity of the xanthophylls, leading to an improvement in the photochemical process. Thus, in this plant growth stage, the results pointed to the failure of adaptation to higher photosynthetic rates, as constitutive levels of chlorophyll are maintained, and there was greater biomass 
incorporation even with an increased nutrient uptake. However, the increase of carotenoid level indicated the need for photoprotection and without this mechanism the photoinhibition could be more severe in plants from less acidic soil conditions.

\section{Conclusions}

Our data support the ecological adaptation of $Q$. cordata growth in impoverished rupestrian field soils and can also explain the distribution pattern of the species in extremely acidic soil with high $\mathrm{Al}$ content. This research revealed that such species is an Al accumulating plant. The slight variation of soil deacidification in the occurrence areas of this species, and other plants with similar ecological chemical soil adaptations, can induce a constraint in the reintroduction process, once it leads to reduced initial growth and its possible plant establishment. Despite the results obtained in controlled conditions, the resilience of this species and also other $\mathrm{Al}$ accumulator plants should be revealed in field conditions, like other environmental constraints that compromise the growth of native plants.

Acknowledgements. The study was supported by Brazilian National Council for Scientific and Technological Development (CNPq) and Post-graduate Program in Vegetal Biology (PPGBV) of the Federal University of Minas Gerais (UFMG). The authors also thank Virgínia A. Dos Reis and Tereza Vale who revised the text in English.

\section{REFERENCES}

[1] Allen, S.E. (1989): Chemical analysis of ecological materials. - Blackwell Scientific Publications: Oxford.

[2] Andrade, L.R.M., Barros, L.M.G., Echevarria, G.F., Amaral, L.I.V., Cotta, M.G., Rossatto, D.R. (2011): Al-hyperaccumulator Vochysiaceae from the Brazilian Cerrado store aluminum in their chloroplasts without apparent damage. - Environmental and Experimental Botany 70: 37-42.

[3] Baligar, V.C., Anghinoni, I., Pitta, G.V.E., Santos, H.L., Cunha Filho, E., Schaffert, R.E. (1995): Aluminum effects on plant and nutrient uptake parameters of soil and solution grown sorghum genotypes. - Journal of Plant Nutrition 18: 2325-2338.

[4] Benites, V.M., Caiafa, A.N., Mendonça, E.S., Schaefer, C.E., Ker, J.C. (2003): Soil and vegetation on the high altitude rocky complexes of the Mantigueira and Espinhaço Mountain. - Brazilian Journal of Forest and Environment 10: 76-85.

[5] Buni, A. (2014): Effects of liming acidic soils on improving soil properties and yield of haricot bean. - Journal of Environmental and Analytical Toxicology 5: 248.

[6] Claessen, M.E.C., Barreto, W.O., Paula, J.L., Duarte, M.N. (1997): Manual de métodos de análises de solos. - EMBRAPA-CNPS: Rio de Janeiro.

[7] Correa, M.P. (1926): Dicionário das plantas úteis do Brasil. - Ministério da Agricultura.

[8] Delitti, W.B.C., Meguro, M., Pausas, J.G. (2006): Biomass and mineralmass estimates in a "cerrado" ecosystem. - Brazilian Journal of Botany 29: 531-540.

[9] França, F. (2015): Vochysiaceae in lista de espécies da flora do Brasil. Jardim Botânico do Rio de Janeiro. (http://floradobrasil.jbrj.gov.br/jabot/floradobrasil/FB15282).

[10] Franco, A.C., Matsubara, S., Orthen, B. (2007): Photoinhibition, carotenoid composition and the co-regulation of photochemical and non-photochemical quenching in neotropical savanna trees. - Tree Physiology 27: 717-725.

[11] Furtini Neto, A.E., Resende, A.V., Vale, F.R., Silva, I.R. (1999): Liming effects on growth 
of native woody species from Brazilian savannah. - Pesquisa Agropecuária Brasileira 34: 829-837.

[12] Hajiboland, R., Rad, S.B., Barceló, J., Poschenrieder, C. (2013): Mechanisms of aluminum-induced growth stimulation in tea (Camellia sinensis). - Journal of Plant Nutrition and Soil Science 176: 616-625.

[13] Haridasan, M. (2000): Nutrição mineral das plantas nativas do cerrado. - Brazilian Journal of Plant Physiology 12: 54-64.

[14] Haridasan, M. (2008): Nutritional adaptations of native plants of the cerrado biome in acid soils. - Brazilian Journal of Plant Physiology 20: 183-195.

[15] Jansen, S., Broadley, M.R., Robbrecht, E., Smets, E. (2002a): Aluminum hyperaccumulation in angiosperms: A review of its phylogenetic significance. - Botanical Review 68: 235-269.

[16] Jansen, S., Watanabe, T., Smets, E. (2002b): Aluminum accumulation in leaves of 127 species in Melastomataceae with comments on the order myrtales. - Annals of Botany 90 : 53-64.

[17] Kochian, L.V., Pineros, M.A., Liu, J., Magalhaes, J.V. (2015): Plant adaptation to acid soils: the molecular basis for crop aluminum resistance. - Annual Review of Plant Biology 66: 571-598.

[18] Lichtenthaler, H.K., Wellburn, A.R. (1983): Determinations of total carotenoids and chlorophylls $a$ and $b$ of leaf extracts in different solvents. - Biochemical Society Transactions 11: 591-592.

[19] Ma, J.F., Hiradate, S. (2000): Form of aluminium for uptake and translocation in buckwheat (Fagopyrum esculentum Moench). - Planta 211: 355-360.

[20] Matsumoto, H., Hirasawa, E., Morimura, S., Takahashi, E. (1976): Localization of aluminum in tea leaves. - Plant and Cell Physiology 17: 627-631.

[21] Nardoto, G.B., Bustamante, M.M.C., Pinto, A.S., Klink, C.A. (2006): Nutrient use efficiency at ecosystem and species level in savanna areas of Central Brazil and impacts of fire. - Journal of Tropical Ecology 22: 191-201.

[22] Olivares, E., Colonnello, G., Pena, E., Rodriguez, L. (2010): Aluminum accumulation in nineteen Melastomataceae species from three contrasting plant formations in acid soils. Journal of Plant Nutrition and Soil Science 173: 453-460.

[23] Oliveira, R.S., Galvão, H.C., Campos, M.C., Eller, C.B., Pearse, S.J., Lambers, H. (2015): Mineral nutrition of campos rupestres plant species on contrasting nutrient-impoverished soil types. - New Phytologist 205: 1183-1194.

[24] Padua, M., Cavaco, A.M., Aubert, S., Bligny, R., Casimiro, A. (2010): Effects of copper on the photosynthesis of intact chloroplasts: interaction with manganese. - Physiologia Plantarum 138: 301-311.

[25] Pilon-Smits, E.A.H., Quinn, C.F., Tapken, W., Malagoli, M., Schiavon, M. (2009): Physiological function of beneficial elements. - Current Opinion in Plant Biology 12: 267-274.

[26] Pinho, L.G.R., Campostrini, E., Monnerat, P.H., Netto, A.T., Pires, A.A., Marciano, C.R., Soares, Y.J.B. (2010): Boron deficiency affects gas exchange and photochemical efficiency (JPI test parameters) in green DWARF coconut. - Journal of Plant Nutrition 33: 439-451.

[27] Poschenrieder, C., Gunse, B., Corrales, I., Barcelo, J. (2008): A Glance into Aluminum toxicity and resistance in plants. - Science of the Total Environment 400: 356-368.

[28] Serrano, H.C., Pinto, M.J., Martins-Loução, M.A., Branquinho, C. (2011): How does an Al-hyperaccumulator plant respond to a natural field gradient of soil phytoavailable Al? Science of the Total Environment 409: 3749-3756.

[29] Shimizu, G.H., Yamamoto, K. (2012): Flora da Serra do Cipó, MG: Vochisiaceae. Boletim de Botânica da Universidade de São Paulo 30: 63-87.

[30] Silva, G.E.A., Ramos, F.T., Faria, A.P., França, M.G.C. (2014): Seeds' physicochemical traits and mucilage protection against aluminum effect during germination and root 
elongation as important factors in a biofuel seed crop (Ricinus communis). Environmental Science and Pollution Research 21: 11572-11579.

[31] Souza, M.C., Bueno, P.C.P., Morellato, L.P.C., Habermann, G. (2015): Ecological strategies of $\mathrm{Al}$-accumulating and non-accumulating functional groups from the cerrado sensu stricto. - Anais da Academia Brasileira de Ciências 87: 813-823.

[32] Souza, R.F., Faquin, V., Andrade, A.T., Torres, P.R.F. (2007): Phosphorus forms in soil under influence of liming and organic fertilization. - Revista Brasileira de Ciência do Solo 31: 1535-1544.

[33] Tripodi, A.D., Sievering, H. (2010): The photosynthetic response of a high-altitude spruce forest to nitrogen amendments with implications for gross primary productivity. - Tellus 62B: 59-68.

[34] Verhoeven, A.S., Demmig-Adams, B., Adams, B.B. (1997): Enhanced employment of the xanthophylls cycle and thermal energy dissipation in spinach exposed to high light and $\mathrm{N}$ stress. - Plant Physiology 113: 817-824.

[35] Wang, W., Zhao, X.Q., Hu, Z.M., Shao, J.F., Che, R.F., Dong, X.Y., Shen, R.F. (2015): Aluminium alleviates manganese toxicity to rice by decreasing root symplastic $\mathrm{Mn}$ uptake and reducing availability to shoots of Mn stored in roots. - Annals of Botany 116: 237-246.

[36] Watanabe, T., Jansen, S., Osaki, M. (2005): The beneficial effect of aluminium and the role of citrate in $\mathrm{Al}$ accumulation in Melastoma malabathricum. - New Phytologist 165: 773-780.

[37] Yang, Y., Liu, Y., Huang, C.F., Silva, J., Zhao, F-J. (2016): Aluminium alleviates fluoride toxicity in tea (Camellia sinensis). - Plant and Soil 402: 179-190. 


\section{APPENDIX}

Appendix 1. Dry weight mass (DW) of root, shoot and total biomass and root: shoot ratio $(R: S)$ of the Qualea cordata plants cultivated for 6 months in two acid soil conditions (pH:4 and $\mathrm{pH}: 5$ ). $\mathrm{N}=10$, SD: standard deviation.

\begin{tabular}{cccc}
\hline & Acid soil & & Less acid soil \\
\hline & DW(SD) & & DW(SD) \\
\hline Root & $0.69(0.20)$ & & $0.39(0.07)$ \\
Shoot & $0.87(0.14)$ & & $0.40(0.07)$ \\
Total & $1.56(0.30)$ & & $0.79(0.20)$ \\
R:S & $0.77(0.77)$ & & $1.04(0.28)$ \\
\hline
\end{tabular}

Appendix 2. Mineral element content ( $m g g W^{1}$ ) in leaves of Qualea cordata plants cultivated for 6 months in two acid soil ( $\mathrm{pH}: 4$ and $\mathrm{pH}: 5)$ conditions, $N=3$.

\begin{tabular}{cccccccc}
\hline \multicolumn{4}{c}{ Acid soil } & & \multicolumn{3}{c}{ Less acid soil } \\
\cline { 1 - 3 } \cline { 6 - 8 } $\mathrm{Fe}$ & 0.28 & 0.32 & 0.36 & & 0.3 & 0.28 & 0.32 \\
$\mathrm{Al}$ & 3.83 & 5.60 & 7.37 & & 0.66 & 0.88 & 1.0 \\
$\mathrm{Mg}$ & 2.64 & 3.25 & 3.86 & & 7.04 & 7.43 & 7.82 \\
$\mathrm{Ca}$ & 11.18 & 10.09 & 9.0 & & 15.4 & 14.19 & 13.0 \\
$\mathrm{~N}$ & 8.44 & 8.92 & 9.44 & & 9.82 & 10.52 & 11.22 \\
$\mathrm{P}$ & 3.3 & 3.80 & 4.29 & & 5.99 & 6.65 & 7.31 \\
\hline
\end{tabular}

Appendix 3. Potential quantum yield values $(F v / F m)$ and effective quantum yield values $\left(\Delta F / F^{\prime} m\right)$ obtained in leaves of Qualea cordata plants cultivated for 6 months in two acid soil ( $\mathrm{pH}: 4$ and $\mathrm{pH}: 5)$ conditions. $N=3$, SD: standard deviation.

\begin{tabular}{cccccc}
\hline & Acid soil & & & \multicolumn{2}{c}{ Less acid soil } \\
\cline { 1 - 2 } \cline { 5 - 6 } & $\mathrm{Fv} / \mathrm{Fm}$ & $\mathrm{F} / \mathrm{F}$ 'm & & $\mathrm{Fv} / \mathrm{Fm}$ & $\mathrm{F} / \mathrm{F}^{\prime} \mathrm{m}$ \\
$6: 30 \mathrm{am}$ & $0.78(0.05)$ & - & & $0.76(0.06)$ & - \\
$7: 00 \mathrm{am}$ & - & $0.68(0.07)$ & & - & $0.69(0.06)$ \\
$7: 30 \mathrm{am}$ & $0.8(0.06)$ & - & & $0.76(0.07)$ & - \\
$8: 00 \mathrm{am}$ & - & $0.66(0.06)$ & & - & $0.67(0.04)$ \\
$8: 30 \mathrm{am}$ & $0.75(0.05)$ & - & & $0.76(0.08)$ & - \\
$9: 00 \mathrm{am}$ & - & $0.22(0.07)$ & & - & $0.35(0.03)$ \\
$9: 30 \mathrm{am}$ & $0.72(0.05)$ & - & & $0.68(0.05)$ & - \\
$10: 00 \mathrm{am}$ & - & $0.42(0.05)$ & & - & $0.37(0.07)$ \\
$10: 30 \mathrm{am}$ & $0.68(0.05)$ & - & & $0.69(0.08)$ & - \\
$11: 00 \mathrm{am}$ & - & $0.36(0.07)$ & & - & $0.43(0.03)$ \\
$11: 30 \mathrm{am}$ & $0.70(0.05)$ & - & & $0.62(0.07)$ & - \\
$12: 00 \mathrm{am}$ & - & $0.31(0.04)$ & & - & $0.32(0.05)$ \\
$12: 30 \mathrm{pm}$ & $0.71(0.05)$ & - & & $0.65(0.05)$ & - \\
$13: 00 \mathrm{pm}$ & - & $0.3(0.03)$ & & - & $0.32(0.01)$ \\
$13: 30 \mathrm{pm}$ & $0.68(0.15)$ & - & & $0.67(0.15)$ & - \\
\hline
\end{tabular}

